Jurnal Independent Fakultas Hukum

\title{
ASAS PERLINDUANGAN ANAK DALAM PERATURAN PEMERINTAH NO. 43 TH 2017 TENTANG PELAKSANAAN RESTITUSI BAGI ANAK KORBAN TINDAK \\ PIDANA
}

Ayu Dian Ningtias

ayudian.ningtias@yahoo.com

Fakultas Hukum Universitas Islam Lamongan

\begin{abstract}
ABSTRAK
Berlakunya PP Nomor 43 Tahun 2017 dilatarbelakangi oleh kenyataan bahwa kejahatan terhadap anak tidak hanya menimbulkan penderitaan fisik maupun psikis yang mempengaruhi tumbuh kembang dan kualitas hidup anak. Namun menimbulkan kerugian materil maupun imateriil bagi pihak keluarga. Oleh karena itu, sangatlah tepat, bila pengertian restitusi diartikan sebagai pembayaran ganti kerugian yang dibebankan kepada pelaku berdasarkan putusan pengadilan yang berkekuatan hukum tetap atas kerugianmateril dan atau imateril yang diderita korban atau ahli warisnya. Penelitian ini menganalisis tentang bentuk perlindungan pada PP Nomor 43 Tahun 2017 apakah sesuai dengan asas perlindungan anak.
\end{abstract}

Kata Kunci : Asas Perlindungan Anak, Restitusi, Anak Korban Tindak Pidana.

\section{PENDAHULUAN}

Maraknya perkosaan yang terjadi dan menimpa anak membuat prihatin berbagai kalangan, mulai dari orang tua, guru-guru, akademisi hingga pemerintah yang kemudian bersama DPR mengeluarkan Undang-Undang No.35 tahun 2014 tentang perubahan atas Undang-Undang Nomor 23 tahun 2002 Tentang Perlindungan anak. Pada saat itu telah ada Undang-Undang Nomor 17 tahun 2016 tentang Penetapan Peraturan Pemerintah Pengganti Undang-Undang

\footnotetext{
${ }^{1}$ https://www.pontianakpost.co.id/restitusi-bagianak-yang-menjadi-korban-kejahatan
}

Nomor 1 tahun 2016 Tentang Perubahan Kedua atas Undang-undang Nomor 23 tahun 2002 tentang Perlindungan anak menjadi Undang-Undang. Ketentuan ini memperberat pidana terhadap pelaku pencabulan anak, dengan ancaman pidana 20 tahun penjara hingga hukuman mati. ${ }^{1}$ Berkaitan dengan fakta bahwa masih sering terjadi kekerasan seksual terhadap anak dan tidak adanya upaya pemberian rehabilitasi secara merata kepada semua korban, Masalah perlindungan hukum dan hak-haknya bagi 
Jurnal Independent Fakultas Hukum

anak-anak merupakan salah satu sisi pendekatan untuk melindungi anak-anak Indonesia. Agar perlindungan hak-hak anak dapat dilakukan secara teratur, tertib dan bertanggung jawab maka diperlukan peraturan hukum yang selaras dengan perkembangan masyarakat Indonesia. ${ }^{2}$

Keadilan yang diberikan oleh penerapan hukum melalui penjatuhan sanksi hukum yang dijatuhkan pada pelaku tidak adil atau tidak sesuai dengan akibat yang ditimbulkannya. Ketidakadilan hukum inilah yang disebut-sebut dapat menjauhkan masyarakat yang tertimpa musibah (menjadi korban suatu kejahatan) untuk bersedia berurusan dengan dunia peradilan.

Tentang pengertian hukum perlindungan anak, beberapa ahli memberikan batasan-batasan sebagai berikut, Arif Gosita mengatakan: "bahwa hukum perlindungan anak sebagai hukum (tertulis) maupun tidak tertulis yang menjamin anak benar-benar dapat melaksanakan hak dan kewajibannya“3 Bismar Siregar menyebutkan :"aspek hukum perlindungan anak lebih dipusatkan kepada hak-hak anak yang yang diatur hukum dan bukan kewajiban, mengingat

\footnotetext{
${ }^{2}$ Wagita Soetodjo, Hukum Pidana Anak, PT. Refika Aditama, Bandung, 2006, hlm. 67
}

secara hukum (yuridis) anak belum dibebani kewajiban“. 4

Dengan berlakunya UndangUndang No.35 tahun 2014 tentang perubahan atas Undang-Undang Nomor 23 tahun 2002 Tentang Perlindungan anak. Pada saat itu telah ada Undang-Undang Nomor 17 tahun 2016 tentang Penetapan Peraturan Pemerintah Pengganti UndangUndang Nomor 1 tahun 2016 Tentang Perubahan Kedua atas Undang-undang Nomor 23 tahun 2002 tentang Perlindungan anak menjadi Undang-Undang dan para pelaku telah dihukum berat tidak serta merta kejahatan seksual anak menurun. Namun para korban anak setidaknya masih bisa berharap masa depan mereka akan lebih baik seiring dengan dikeluarkannya PP Nomor 43 Tahun 2017 tanggal 16 Oktober 2017 tentang Pelaksanaan Restitusi Bagi Anak Yang Menjadi Korban Tindak Pidana. Restitusi ini diharapkankan menjadi pintu gerbang yang baru bagi anak-anak korban kekerasan seksual untuk menata kembali hidup mereka serta mengejar cita-cita setinggi-tingginya.

Berlakunya PP Nomor 43 Tahun 2017 dilatarbelakangi oleh kenyataan bahwa kejahatan terhadap anak tidak hanya menimbulkan penderitaan fisik maupun

3 Irma Setyowati Soemitro, Aspek Hukum Perlindungan Anak, Jakarta: Bumi Aksara, 1990, h. 15. 
Jurnal Independent Fakultas Hukum

psikis yang mempengaruhi tumbuh kembang dan kualitas hidup anak. Namun menimbulkan kerugian materil maupun imateriil bagi pihak keluarga. Oleh karena itu, sangatlah tepat, bila pengertian restitusi diartikan sebagai pembayaran ganti kerugian yang dibebankan kepada pelaku berdasarkan putusan pengadilan yang berkekuatan hukum tetap atas kerugianmateril dan atau imateril yang diderita korban atau ahli warisnya. Penelitian ini menganalisis tentang bentuk perlindungan pada PP Nomor 43 Tahun 2017 apakah sesuai dengan asas perlindungan anak.

\section{METODE PENELITIAN}

Melalui penelitian yuridis normatif akan diteliti tentang bentuk perlindungan anak korban perkosaan dan bagaimana perbedaaan anatara rehabilitasi dan restitusi, untuk itu akan dianalisa berdasarkan teori-teori hukum, prinsipprinsip hukum, doktrin-doktrin hukum seta peraturan perundang-undangan yang terkait. Dalam penelitian ini menggunakan Pendekatan perundang-undangan (statute approach), dan Pendekatan konseptual (conceptual approach).

Pendekatan perundangan-undangan (statute approach) diperlukan guna

${ }^{5}$ ibid.

6 Peter Mahmud Marzuki, Metode Penelitian Hukum. Kencana, Jakarta 2005, h.1. mengkaji lebih lanjut mengenai dasar hukum. Pendekatan perundang-undangan dilakukan dengan menelaah semua undangundang dan regulasi yang bersangkut paut dengan isu hukum. ${ }^{5}$ Pendekatan perundang-undangan ini dimaksudkan untuk mengkaji dan menganalisis terhadap peraturan perundang-undangan yang berkaitan dengan isu hukum terkait. ${ }^{6}$

\section{III.HASIL PEMBAHASAN}

PP Nomor 43 Tahun 2017 ini menjamin hak anak korban kejahatan untuk mendapatkan restitusi. Ditegaskan bahwa setiap anak yang menjadi korban tindak pidana berhak memperoleh restitusi. Adapun Kualifikasi anak korban kejahatan yang mendapat restitusi terdiri atas Pertama anak yang berhadapan dengan hukum. Kedua anak yang dieklpoitasi secara ekonom dan/atau seksual. Ketiga anak yang menjadi korban pornografi. Keempat Anak korban penculikan, penjualan, dan/atau perdagangan. Kelima anak Korban kekerasan fisik dan/ atau. Keenam anak korban kejahatan seksual. Khusus bagi anak yang berhadapan dengan hukum, restitusi diberikan kepada anak korban. Restitusi yang diberikan kepada anak yang berhadapan dengan hukum berupa ganti 
Jurnal Independent Fakultas Hukum

kerugian atas kehilangan kekayaan, ganti kerugian atas penderitaan sebagai akibat tindak pidana dan/atau penggantian biaya perawatan medis dan /atau psikologis.

Pengajuan restitusi dapat diajukan oleh pihak korban. Dalam hal ini pihak korban terdiri dari orang tua atau wali anak yang menjadi korban tindak pidana, ahli waris anak yang menjadi korban tindak pidana, dan orang yang diberi kuasa oleh orang tua, wali atau ahli waris anak yang menjadi korban tindak pidana dengan surat Kuasa Khusus. Jika pihak yang mengajukan restitusi terlibat sebagai pelaku, maka pengajuan restitusi dapat dilakukan oleh Lembaga Perlindungan Saksi dan Korban (LPSK).

Permohonan restitusi diajukan secara tertulis di atas materai ke Pengadilan. Permohonan tersebut dapat diajukan dalam tahap penyidikan, Penuntutan dan pasca Putusan Pengadilan yang telah mendapat kekuatan hukum tetap. Khusus yang terakhir ini, permohonan dapat dilakukan oleh LPSK.

Pemberian Restitusi dilaksanakan dengan cara sebagai berikut: pertama panitera Pengadilan mengirimkan salinan penetapan yang berkekuatan hukum tetap yang memuat pemberian restitusi kepada

${ }^{7}$ Dikdik M. Arief Mansur-Elisatris Gultom, Urgensi Perlindungan Korban Kejahatan-Antara
Jaksa. Kedua dalam waktu tujuh hari sejak diterimanya putusan tersebut, Jaksa wajib menyampaikan kepada pelaku dan pihak korban. Ketiga pelaku wajib memberikan restitusi kepada pihak korban dalam jangka waktu 30 (tiga puluh) hari sejak diterimanya salinan putusan tersebut, dalam Berita Acara Pelaksanaan Putusan. Jika Pelakunya adalah anak, maka pemberian restitusi dilakukan oleh orang tuanya. Keempat, setelah pelaku memberikan restitusi kepada pihak korban, ia wajib melaporkan kepada Pengadilan dan Kejaksaan. Kelima, setelah itu Pengadilan mengumumkan pelaksanaan pemberian restitusi, baik melalui media elektronik maupun non elektronik.

Dikeluarkannya Peraturan Pemerintah ini setidaknya memberikan secercah harapan, dan mengakomodir kerugian para korban khsusnya anak yang mengalami kerugian materil maupun immatril akibat kekerasan seksual yang dialaminya, dan diharapkan korban-korban kekerasan seksual masih dapat menatap masa depannya atau melanjutkan sekolahnya demi masa depannya.

Konteks pemulihan terhadap korban dalam bentuk restitusi terkandung pula beberapa asas asas hukum sebagai berikut: ${ }^{7}$

Norma dan Realita,PT. RadjaGrafindo Persada, Jakarta,2007, h. 164. 
1. Asas Manfaat

Artinya, perlindungan korban kejahatan tidak hanya ditujukan bagi tercapainya kemanfaatan (baik materiil maupun spiritual) bagi korban kejahatan, tetapi juga kemanfaatan bagi masyarakat luas, khususnya dalam upaya mengurangi jumlah tindak pidana serta menciptakan ketertiban masyarakat.

2. Asas Keadilan

Artinya, penerapan asas keadilan dalam upaya melindungi korban kejahatan tidak bersifat mutlak karena hal ini dibatasi pula oleh rasa keadilan yang harus juga diberikan pada pelaku kejahatan.

3. Asas Keseimbangan

Tujuan hukum disamping memberikan kepastian dan perlindungan terhadap kepentingan manusia, juga untuk memulihkan keseimbangan tatanan masyarakat yang terganggu menuju pada kekayaan yang semula (restitution in integrum), asas keseimbangan memperoleh tempat yang penting dalam upaya pemulihan hak-hak korban.

4. Asas Kepastian Hukum

Asas ini dapat memberikan dasar pijakan hukum yang kuat bagi aparat penegak hukum pada saat melaksanakan tugasnya dalam upaya memberikan perlindungan hukum pada korban kejahatan.

Selain dari pada itu peran masyarakat dalam membantu para anak korban kekerasan seksual sangatlah dibutuhkan sebagai suplemen bagi anak untuk tidak terus terpuruk dari rasa frustasi, hingga anak-anak ini mampu kembali bangkit dan bersaing dalam mengejar cita- citanya. Namun yang lebih penting dari ini semua adalah peran orang tua serta lingkungan terdekat anak untuk menjaga serta melindungi mereka dari pergaulan serta orang-orang yang mungkin membahayakan mereka.

\section{KESIMPULAN}

Peraturan Pemerintah (PP) Nomor 43

Tahun 2017 tentang Pelaksanaan Restitusi bagi Anak Korban Tindak Pidana memudahkan anak yang menjadi korban tindak pidana untuk mengajukan hak atas restitusi ke pengadilan yang menjadi tanggung jawab pelaku kejahatan. PP ini memenuhi asas perlindungan bagi anak korba, dengan PP restitusi ini memudahkan aparat penegak hukum dalam tataran praktik atau pelaksanaan pemenuhan hak anak korban tindak pidana untuk mendapatkan restitusi.

\section{DAFTAR BACAAN}

Dikdik M. Arief Mansur-Elisatris Gultom, Urgensi Perlindungan Korban Kejahatan- Antara Norma dan Realita,PT. RadjaGrafindo Persada, Jakarta,2007.

Irma Setyowati Soemitro, Aspek Hukum Perlindungan Anak, Jakarta: Bumi Aksara, 1990.

Peter Mahmud Marzuki, Metode Penelitian Hukum. Kencana, Jakarta, 2005.

Wagita Soetodjo, Hukum Pidana Anak, PT. Refika Aditama, Bandung, 2006. https://www.pontianakpost.co.id/restitusibagi-anak-yang-menjadi-korbankejahatan. 